\title{
Ethnomedicinal investigations among the Baiga tribes, district Anuppur, Madhya Pradesh, India
}

\author{
Ramesh Kumar Ahirwar ${ }^{\square}$ \\ Department of Botany, Government College Birsinghpur Pali, Umaria, Madhya Pradesh - 484551, India \\ 凶Corresponding author: dr.rkahirwar@gmail.com \\ भारत, मध्य प्रदेश के अनूपपुर जिले की बैगा जनजातियों में \\ लोकऔषधीय अन्वेषण
}

\section{रमेश कुमार अहिखार}

\section{सारांश}

जनवरी 2015 से जनवरी 2016 तक बैगा जनजाति द्वारा उपयोग किये गये औषधीय पौधों के दस्तावेज बनाने के लिए मध्य प्रदेश के अनूपपुर जिले में जातीय समूह (बैगा जनजाति) में लोकऔषधीय पादप अध्ययन किया गया। 44 वंश एवं 39 कुलों से संबंधित 68 पौधों का पारम्परिक उपयोग इस जनजाति के द्वारा त्वचा रोगों, अतिसार, पीलिया, खांसी, घावों, बवासीर, मूत्र संबंधी परेशानियों, अस्थमा, तपेदिक, सर्पदंशन, स्त्रीरोग संबंधी समस्याओं, हृदय रोगों, और आईड्रॉप के रूप में किया जाता है।

\section{ABSTRACT}

The ethnobotanical study was carried out among the ethnic group (Baiga tribe) in the Anuppur district of Madhya Pradesh during January 2015 to January 2016 to document the medicinal plants used by the Baiga tribe. Traditional uses of 68 plant species belonging to 44 genera and 39 families used to cure skin diseases, diarrhoea, jaundice, cough, wounds, piles, urinary troubles, asthma, tuberculosis, snakebite, gynaecological problems, heart diseases and as an eye drop are reported here.

Keywords: Ethnomedicine, Baiga Tribe, Traditional Medicine, Madhya Pradesh

\section{INTRODUCTION}

The Baigas are one of the oldest indigenous tribes in Madhya Pradesh and concentrate in the forests, hilly tracks of Baigachak area of Dindori, Annupur district (Brijlal, 1988; Tiwari 1984). The traditional art of tattoos, 'Godna' designing, is widespread among this tribe and the womenfolk of Baiga tribes usually engrave this typical design on their body parts, particularly on faces with a believe that it would help them to identify in heaven (Elwin, 1986). Due to the remote ness of their locality, the local inhabitants are still depend on forests for their social, culture and economic survival. They also do collect various medicinal plants used in their indigenous formulations (Tripathi \& al., 2013). A number of sporadic valuable reports on ethno medicinal plants of the district Anuppur have been published from time to time (Ahirwar, 2010; Saini, 2007, Kumar \& al., 2004). However, the vast store of ethnomedicinal information of these study areas has not been fully documented. The various traditional practices of treatments which need to be recorded, before it surpasses by the modern methods. The present study enumerates 
the various medicinal plants used during the traditional healing practices of Baiga tribes from the Pushprajgarh region of Anuppur district of Madhya Pradesh.

\section{THE STUDY AREA}

The district Anuppur in Madhya Pradesh located between $23^{\circ} 15^{\prime}$ to $24^{\circ} \mathrm{N}$ Latitude and $81^{\circ} 0$ ' to $81^{\circ} 45^{\prime} \mathrm{E}$ Longitude, covering an area of 3701 sq. $\mathrm{km}$. The district is surrounded by Korea district (Chhattisgarh) in the East, Dindori district in the West, Shahdol district in North and Northwest district in Umaria (Figure 1). This region is popularly known as the Plateau of BeghelKhand for its rich and diverse flora. The Pushprajgarh regions of Anuppur district mostly inhabited by Gond, Baiga, Panika, Kol, Agaria tribes in sporadic remote hill tracts. The total population of the study site is 194,574 . The maximum temperature goes up to $45{ }^{\circ} \mathrm{C}$ in the month of May and minimum recorded is $20^{\circ} \mathrm{C}$ in the month of January. The area has been categorised as Central India sub-tropical forest endowed with various forest as natural resources.

\section{METHODS}

Ethnobotanical surveys were conducted in different tribal inhabited localities of Pushprajgarh region during January 2015 to January 2016. The 11 tribal villages

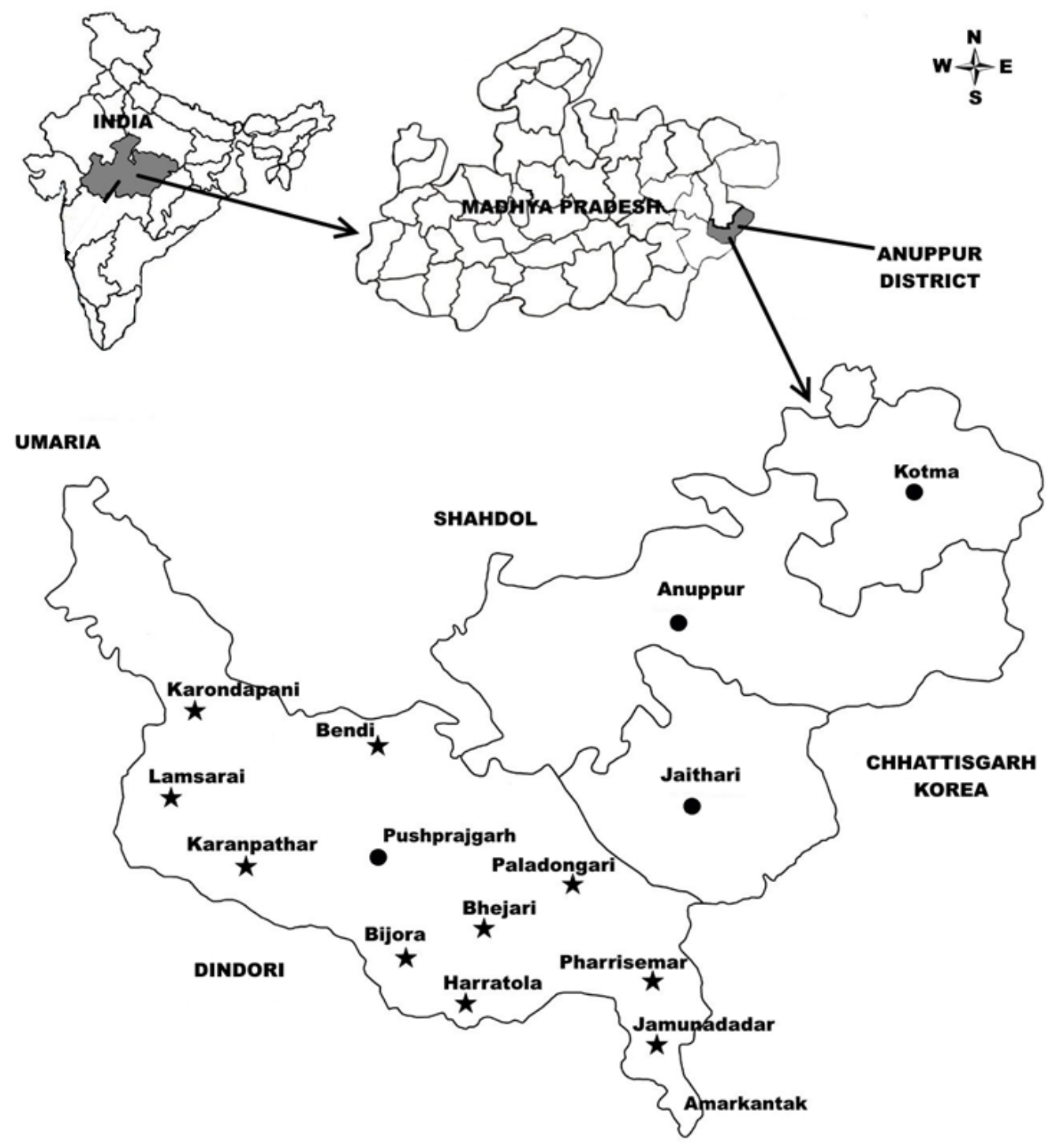

Fig. 1: Location map of study area Pushprajgarh block, Anuppur, Madhya Pradesh 
of Pushprajgarh block covered in the present studies, includes Jamunadadar, Bhejari, Pushprajgarh (Rajendragram) Pharrisemar, Bendi, Karanpathar, Lamsarai, Karondapani, Bijora, Paladongri and Harratola. The elderly and experienced traditional healers, local Vaidyas or Guniya those actively engaged in ethno-medicinal practices, were interviewed after their prior informed consent were taken. A written permission to publish their traditional knowledge was also obtained from the Baiga tribal communities. The detailed information such as plant name, parts used, mode of preparation, mode of application, dose and duration etc. have been collected with the help of prescribed questionnaire. The voucher specimens were also collected, identified with the help of local floras and preserved in the herbarium of Department of Botany, Pandit Sambhu Nath Shukla Government Post Graduate College, Shahdol, Madhya Pradesh. The recorded uses were compared with wellknown Indian literature and found that these uses are not been published before (Saxena, 1970; Verma \& al., 1993; Mudgal \& al., 1997; Singh \& al., 2001). The plants are enumerated alphabetically with their botanical name followed by family, local name, voucher number and uses for different ailments/diseases.

\section{ENUMERATION}

1. Abrus precatorius L. (Leguminosae), Ghumchi, RKAP108.

Uses: Two spoonful of seed paste (red variety) is given orally once daily before breakfast for 3 days to cure menstrual disorder.

2. Abutilon indicum (L.) Sweet (Malvaceae), Kanghi, RKAP139.

Leaves are boiled in coconut oil and the oil is externally applied on head once daily for one week to cure cold and scabies on the head.

3. Acacia nilotica (L.) Delile (Leguminosae), Bamoor, RKAP05.

Fresh leaf paste $(20 \mathrm{gm})$ is externally applied on anus daily in the morning after bath for 15 days to cure piles.

4. Achyranthes aspera L. (Amaranthaceae), Lathjira, RKAP134.

Root paste is externally applied on affected area immediately after scorpion sting.

5. Adhatoda vesica Nees (Acanthaceae), Adusa, RKAP89.
Leaf juice $(5 \mathrm{ml})$ with equal quantity of goat's milk is given thrice daily for 21 days to cure whooping cough.

6. Alpinia calcarata (Haw.) Roscoe (Zingiberaceae), Kulanjan, RKAP12.

Root in small pieces, chewed once in a day for 4 times to cure sore throat.

7. Andrographispaniculata(Burm.f.) Nees(Acanthaceae), Chirayta, RKAP156.

Decoction of the whole plant $(15 \mathrm{ml})$ is given orally thrice in a day for 7 days to cure respiratory disorder.

8. Anogeissus latifolia (Roxb. ex DC.) Wall. ex Guillem. \& Perr. (Combretaceae), Dhava, RKAP205.

Stem bark decoction $(10 \mathrm{ml})$ is given orally once daily before breakfast for a week to prevent menstruation disorders.

9. Argemone mexicana L. (Papaveraceae), Peli kateli, RKAP213.

Root paste is externally applied for eczema and itching. 10. Asparagus racemosus Willd. (Asparagaceae), Satavar, RKAP57.

Fresh tuber juice $(15 \mathrm{ml})$ mixed with a cup of cow's milk is given orally twice in a day for 10 days to cure haematuria.

11. Azadirachta indica A. Juss. (Meliaceae), Neem, RKAP78.

Leaf juice $(10 \mathrm{ml})$ mixed with a cup of water is given orally once in a day before breakfast for 7 days to prevent miscarriage.

12.Bacopa monnieri (L.) Wettst. (Plantaginaceae), Jalneem, RKAP168.

Leaf juice (2 drops) instilled into ears and at the same time, leaf paste $(10 \mathrm{gm})$ is externally applied on the bitten area just after snake-bite.

13.Barleria prionitis L. (Acanthaceae), Vajradanti, RKAP172.

Leaves are boiled in water and tied on boils for one night.

14.Bauhinia vahlii Wight \& Arn. (Leguminosae), Mahulain, RKAP62.

Rhizome paste is applied on affected area once in a day before bedtime for a week to cure mouth ulcers.

15.Bauhinia variegata L. (Leguminosae), Kachnar, RKAP103.

A spoonful of sun dried flower bud powder mixed with a cup of water is given orally twice in a day for 21 days to cure piles.

16. Boerhavia diffusa L. (Nyctaginaceae), Punarnava, RKAP15. 
Root decoction $(10 \mathrm{ml})$ mixed with a cup of water is given thrice in a day for 7 days to cure jaundice.

17. Bombax ceiba L. (Malvaceae), Semur, RKAP10.

Stem bark paste is externally applied to cure burns.

18. Boswellia serrata Roxb. ex Colebr. (Burseraceae), Salai,

RKAP24.

Seed powder $(5 \mathrm{gm})$ mixed with a cup of water given twice in a day for one month to cure tuberculosis.

19. Bryonia laciniosa L. (Cucurbitaceae), Shivlingi, RKAP20.

A teaspoonful crushed seed with a glass of water is given orally once in the morning before breakfast for 3 months to cure sterility in women.

20. Buchanania lanzan Spreng. (Anacardiaceae), Chironji, RKAP118.

Leaf juice $(15 \mathrm{ml})$ mixed a cup of water taken twice in a day for 2 days to prevent dysentery.

21.Butea monosperma (Lam.) Taub. (Leguminosae),

Chheula, RKAP202.

Flowers are boiled in water and the water is used to take bath for 3 days to cure mild fever among children. This practice is also used to cure jaundice.

22. Calotropis procera (Aiton) Dryand. (Apocynaceae), Madar, RKAP184.

Dried twig is smoked like a 'Beedi' in the morning once daily for 3 days to cure migraine.

23. Gerascanthus macleodii (Hook. f. \& Thomson) Borhidi

(Boraginaceae), Dahiman, RKAP179.

Seed paste $(20 \mathrm{gm})$ is given orally with added sugar lump (Misri) $10 \mathrm{gm}$ once in a day in the morning before breakfast for 40 days to get relief from insanity.

24. Cassia fistula L. (Leguminosae), Amaltas, RKAP07.

A teaspoonful of root bark powder mixed with a glass of water is given orally twice in a day for 21 days to cure piles.

25. Cassia tora L. (Leguminosae), Chakauda, RKAP68.

Leaf paste is externally applied to cure skin diseases, especially eczema.

26. Centella asiatica (L.) Urb. (Apiaceae), Brahmibooti, RKAP154.

Whole plant extract ( $5 \mathrm{ml}$ ) mixed with a cup of water is taken orally once daily for 21 days to cure diabetes.

27. Curculigo orchioides Gaertn. (Hypoxidaceae), Kali musali, RKAP122.

Decoction of fresh rhizome $(10 \mathrm{ml})$ mixed with a cup of water is given orally twice in a day for 7 days to cure leucorrhoea.
28. Cuscuta reflexa Roxb. (Convolvulaceae), Amerbel, RKAP28.

Stem paste $(20 \mathrm{gm})$ with 2-3 seeds of black pepper powder (Piper nigrum L.) is mixed and the paste is given orally once in the morning on empty stomach for 3 days to cure jaundice.

29. Costus speciosus (J. Koenig) Sm. (Costaceae), Keukand, RKAP36.

Boiled rhizome extract $(10 \mathrm{ml})$ mixed with a cup of water is taken orally twice in a day for 20 days to cure heart problems.

30.Cynodon dactylon (L.) Pers. (Poaceae), Doobi, RKAP125.

Whole plant juice $(30 \mathrm{ml})$ mixed with a glass of cow's milk is given orally once at the bedtime for 3 days to cure bleeding during pregnancy.

31.Cyperus rotundus L. (Cyperaceae), Nagarmotha, RKAP128.

Rhizome extract $(5 \mathrm{ml})$ with one teaspoonful of honey is to take orally thrice daily for 3 days to cure diarrhoea.

32. Datura metel L. (Solanaceae), Dhatura, RKAP33.

Fruit paste with mixed mustard oil is externally applied twice in a day for 15 days to cure skin diseases.

33.Diospyros melanoxylon Roxb. (Ebenaceae), Tendu, RKAP170.

The root bark paste is applied on forehead twice in a day for 3 days to cure headache.

34. Euphorbia hirta L. (Euphorbiaceae), Dudhi, RKAP208.

Whole plant powder $(10 \mathrm{gm})$ mixed in a glass of cow's milk, added with a teaspoonful sugar lump, (Misri) is given orally once in the morning before breakfast for 45 days to cure leucorrhoea.

35. Euphorbia neriifolia L. (Euphorbiaceae), Senhur. RKAP187.

Leaf paste is externally applied once in a day for 2 days to cure boils.

36. Ferula foetida St.-Lag. (Apiaceae), Heeng, RKAP92.

Oleo-gum-resin (5 gm) (It's obtained from the rhizome and root of the plant) is mixed with a cup of lukewarm water and applied on the stomach of the child, twice in a day for 3 days to cure flatulence.

37. Ficus racemosa L. (Moraceae), Dumer, RKAP149.

Flower buds ( 7 buds at a time) which is ground well and mixed with a glass of cow's milk is consumed after dinner for 4 months to cure infertility in women.

38. Ficus religiosa L. (Moraceae), Peepal, RKAP53. 
Bark ash (5 gm), mixed with boiled water, is applied on the breast to cure breast abscess.

39. Gloriosa superba L. (Colchicaceae), Kalihari, RKAP50.

Fresh root paste $(20 \mathrm{gm})$ and 3 fruits of black pepper (Piper nigrum L.) are mixed in a glass of lukewarm goat's milk and it is given orally once at the bedtime for 3 days of pregnancy, which can be up to 3 months, for abortifacient.

40. Grewia hirsuta Vahl (Malvaceae), Nagbela, RKAP69.

Leaf decoction $(10 \mathrm{ml})$, mixed with a cup of water, is consumed twice in a day for 3 days for the treatment of dysentery.

41. Gymnema sylvestre (Retz.) R. Br. ex Sm. (Apocynaceae),

Gudmar, RKAP106.

Root paste along with 7 fruits of black pepper (Piper nigrum L.) are taken in equal ratio to make a paste and the paste is externally applied on the bitten area of a snake-bite.

42. Hedychium coronarium J. Koeing (Zingiberaceae),

Gulbakavali, RKAP115.

Two drops of flower arrack is dripped into human eyes thrice in a day for 15 days to prevent cataract (Motiabind). 43. Helicteres isora L. (Malvaceae), Marorphali, RKAP164.

Seed powder $(5 \mathrm{gm})$ mixed in a glass of water is given orally twice in a day for 3 days in case of gastroenteritis. 44. Ipomoea carnea Jacq. (Convolvulaceae), Beshram, RKAP210.

Leaf paste is externally tied on boils for 2 days. 45. Ipomoea pes-tigridis L. (Convolvulaceae), Panchpatiya, RKAP182.

Leaf paste is externally applied on the affected area just after scorpion bite. Meanwhile, two spoonsful is given orally with a cup of water.

46. Jatropha curcas L. (Euphorbiaceae), Bhakrenda, RKAP71.

Latex of stem is externally applied on wounds twice in a day for 5 days to cure wounds of animals.

47. Kigelia pinnata (Jacq.) DC. (Bignoniaceae), Balamkhira, RKAP85.

Fruit juice $(5 \mathrm{ml})$ is mixed in a cup of water and it is given orally twice in a day for 3 days to cure stomach disorder.

48. Lantana camara L. (Verbenaceae), Barmasiya, RKAP159.

A teaspoonful of leaf juice mixed in a glass of water given once in a day orally to cure vomiting.

49. Madhuca longifolia (J. Koeing ex L.) J.F.Macbr. (Sapotaceae), Mahua, RKAP199.
Decoction of bark $(10 \mathrm{ml})$, mixed with a glass of water, is given orally twice in a day for 3 days to cure stomachache.

50. Mucuna pruriens (L.) DC. (Leguminosae), Kevanch, RKAP194.

A teaspoonful of sun-dried powder, mixed with a glass of water, is given orally once daily for 7 days to remove intestinal worms.

51. Nyctanthes tristis Salisb. (Oleaceae), Harsingar, RKAP96.

Leaf juice (5 ml) mixed with a cup of water is given orally twice in a day for 20 days as a cure for excessive thirst and loss of weight caused by diabetes.

52.Phyllanthus emblica L. (Phyllanthaceae), Amla, RKAP39,

A teaspoonful of fruit powder, diluted in a glass of water, is given orally once in the morning before breakfast for 15 days to cure leucorrhoea.

53. Plumbago zeylanica L. (Plumbaginaceae), Chitrak, RKAP190.

A teaspoonful of sun dried root powder is diluted in a cup of boiled water to make a paste and the paste is externally applied twice in a day on affected area for 3 months to cure leukoderma.

54. Pongamia pinnata (L.) Pierre (Leguminosae), Karanj,

RKAP146.

Seed oil is applied twice in a day for one month on the affected area to cure rheumatism.

55. Psidium guajava L. (Myrtaceae), Beehi, RKAP100.

A teaspoonful of leaf juice is given orally twice in a day for 15 days to cure mouth ulcers.

56. Pterocarpus marsupium Roxb. (Leguminosae), Beeja,

RKAP65.

A cup of filtrate, which is filtered from the water used for soaking its bark for a night, is consumed on empty stomach once in a day for 3 months to cure diabetes.

57. Pueraria tuberosa (Willd.) DC. (Leguminosae), Bidarikand, RKAP82.

A teaspoonful of sun-dried twigs' powder mixed with a cup of cow's milk is given orally on empty stomach twice in a day for 21 days to cure aphrodisiac.

58. Ricinus communis L. (Euphorbiaceae), Rendi, RKAP11.

Leaves are boiled in water and the water is used for bathing once in a day for one month to cure scabies.

59. Rauvolfia serpentina (L.) Benth. ex Kurz

(Apocynaceae), Sarpagandha, RKAP196. 
Root paste $(10 \mathrm{ml})$ mixed with a cup of water is given orally twice in a day for 2 days in case of rat bite.

60. Shorea robusta Gaertn. (Dipterocarpaceae), Sarai, RKAP74.

A teaspoonful of sun dried gum powder mixed with a cup of curd is given orally twice in a day for 3 days to cure dysentery.

61. Terminalia arjuna (Roxb. ex DC.) Wight \& Arn.

(Combretaceae), Arjun, RKAP43.

Leaf juice $(5 \mathrm{ml})$ mixed with a cup of water is given orally twice in a day for 15 days to cure wart.

62. Terminalia bellirica (Gaertn.) Roxb. (Combretaceae),

Bahera, RKAP137.

Fruit decoction $(100 \mathrm{ml})$ is given orally once daily in the morning before breakfast for a week to cure piles.

63. Terminalia chebula Retz. (Combretaceae), Harra, RKAP144.

Equal quantity of fruits of (Trifla Harra, Bahera and Amla powder) Terminalia chebula Retz., Terminalia bellirica (Gaertn.) Roxb., Phyllanthus emblica L. is ground to make powder. One teaspoonful of the powder is mixed with half teaspoonful of honey and given orally twice in a day for 3 months to cure asthma.

64. Tinospora cordifolia (Willd.) Miers (Menispermaceae),

Gurja, RKAP87.

Stem paste $(150 \mathrm{gm})$ diluted in a glass of water, is given orally twice in a day for 5 days to prevent haematuria.

65. Tribulus terrestris L. (Zygophyllaceae), Gokhru, RKAP48.

Stem juice $(10 \mathrm{ml})$ mixed with a cup of water is given orally once daily in the morning before breakfast for 7 days to cure leucorrhoea.

66. Withania somnifera (L.) Dunal (Solanaceae), Aswagandha, RKAP131.

A teaspoonful of leaf paste mixed with a cup of cow's milk is given orally once daily in the morning before breakfast for 21 days to cure asthma.

67. Woodfordia tomentosa Bedd. (Lythraceae), Dhawa, RKAP44.

A teaspoonful of sun dried flower powder is diluted in a cup of water and given orally twice in a day for 3 days to cure diarrhoea.

68.Ziziphus nummularia (Burm. f.) Wight \& Arn.

(Rhamnaceae), Jharberi, RKAP177.

A teaspoonful of root paste $(10 \mathrm{ml})$, mixed with a cup of water, is given orally for easy delivery.

\section{CONCLUSION}

The present study, reports 68 plant species belonging to 44 genera and 39 families that were used traditionally among the Baiga tribal communities. The plants are used to cure the most common diseases amongst the local people. The above listed formulations need to be scrutinized pharmacognostically as well as pharmacologically. The phytochemical analysis should also be undertaken for the scientific validation of the folklore claims. So, these valuable formulations can be put into manifold use.

\section{REFERENCES}

AHIRWAR, R. K. 2010. A Survey of Medicinal Plants Used by Tribals of Anuppur District, Central India. Ind. J. App. Pure Bio. 25(2): 227-230.

BRIJLAL 1988. Ethnobotanical studies of the Baigas in Baigachak region in Madhya Pradesh, Bull. Trib. Dev. Inst. 16(1): 29-35.

ELWIN, V. 1986. The Baigas, It Reprint in India, Gian Publishing House, Delhi.

KUMAR, R., M. R. SUMAN AND S. S. DASH. 2004. Traditional uses of plants by tribals of Amarkantak region, Madhya Pradesh. Indian J. Tradit. Know. 3(4): 383-390.

MUDGAL, V., K. K. KHANNA AND P. K. HAJRA, 1997. Flora of Madhya Pradesh, Vol, II, Botanical Survey of India, Calcutta. pp 681.

SAINI, D. C. 2007. Traditional use of Pteridophytic plants among Baiga Tribe of Rajendragram in Anuppur District, Madhya Pradesh. In: PC Trivedi (ed.) Palaeobotany to Modern Botany, Pointer Publishers, Jaipur, 71-90.

SAXENA, H. O. 1970. The Flora of Amarkantak (Madhya Pradesh). Bull. Bot.Surv. India 12(1-4): 37-66.

SINGH, N. P., K. K. KHANNA, V. MUDGAL AND R. D. DIXIT. 2001. Flora of Madhya Pradesh, Vol. III, Botanical Survey of India, Calcutta. pp 587.

TEWARI, D. N. 1984. Primitive Tribes of Madhya Pradesh, Ministry of Home Affairs, Govt. of India, New Delhi.

TRIPATHI, M. AND R. L. S. SIKARWAR. 2013. Some traditional herbal formulations of Chitrakoot region, Madhya Pradesh, India. Indian J. Tradit. Know. 12(4): 315-320.

VERMA, D. M., N. P. BALAKRISHNAN AND R. D. DIXIT 1993. Flora of Madhya Pradesh, Vol. I, Botanical Survey of India, Calcutta. pp. 668 